\title{
EFFECT OF DIFFERENT THAWING TECHNIQUES ON COLOR OF BLACK SEA TROUT (Salmo labrax PALLAS, 1814) FILLETS
}

\author{
Ekrem Cem ÇANKIRILIGIL ${ }^{1 *}$ Esen ALP ERBAY ${ }^{1 \oplus}$ \\ ${ }^{1}$ Central Fisheries Research Institute, Trabzon/TURKEY \\ "Corresponding Author: cem.cankiriligil@tarim.gov.tr
}

\begin{abstract}
In this research, effect of different thawing techniques on the meat color of Black Sea trout (Salmo labrax) was evaluated. The commonly using fish thawing methods by the consumers were applied to frozen fish fillets and the color losses were determined. For this purpose, 70 individuals of Black Sea trout were used. First of all, trouts were washed, cleaned and filleted before the freezing stage. In the latter, fillets were kept at $-20^{\circ} \mathrm{C}$ for 7 days in deep-freezer and frozen fillets were thawed with 4 different thawing techniques such as thawing in room temperature $\left(+25^{\circ} \mathrm{C}\right)$, immersion in water $\left(+15^{\circ} \mathrm{C}\right)$, in refrigerator $\left(+4^{\circ} \mathrm{C}\right)$ and in microwave (defrost option). Finally, color characteristics of thawed fillets were determined. According to the results, while the most similar color profile to fresh Black Sea trout meat was detected on thawed in refrigerator at $+4^{\circ} \mathrm{C}$, most color loss was observed in microwaved ones. In view of the results and considering food safety, thawing of frozen fish fillets in refrigerator $\left(+4^{\circ} \mathrm{C}\right)$ is more convenient.
\end{abstract}

Keywords: Thawing, Color, Salmo trutta labrax, Quality Loss, Fish Fillet, Freezing

Received: 01.11.2017 Accepted: 07.12.2017 $\leftrightarrow$ Published: 20.12.2017

\section{INTRODUCTION}

In Europe, some Salmonidae species especially Atlantic Salmon is cultured extensively for a long time [1,2]. Black Sea trout, Salmo labrax (accepted) or Salmo trutta labrax (synonym) [3] is an endemic species of Salmonidae and it is distributing naturally in the northeastern rivers of Turkey and the Black Sea [4]. Also, culture of Black Sea trout being widespread recent years in Turkey [5]. Despite expanding aquaculture, scientific researches about meat quality of this species are not enough. Black Sea trout as a rich nutrient source in terms of protein and essential fatty acids for human beings must be well preserved to avoid from microbial, oxidative and enzymatic spoilages before delivering to the consumers.

As well known, one of the preservation methods is freezing. Quality of frozen fish is dependent not only on the freezing itself but also on processing during catching, slaughtering, cold storage with the initial quality of fresh fish [6-8]. The implementation of freezing meat and meat products to prolong the shelf-life has been practiced for thousands of years. Frozen storage is an important preservation method for fish and fish products where it can affect the quality [9]. Fish commonly preferred for its health improving properties which is very sensitive to thawing process due to their low connective tissue content causes rapid spoilage. Freezing and thawing mainly influence the water fraction of fish fillets where the growth of ice crystals causes osmotic removal of water, denaturation of protein and mechanical damage. Enzymes and other components like color pigments are released. That's why one of the most obvious quality changes caused by thawing is in color $[10,11]$.

Chemical properties with conformational stability and biochemical features in biological systems depend on interaction of their constituent groups with the surrounding medium [12]. Freezing and frozen storage contribute to textural changes $[13,14]$. Once the water freezes, the concentration of the remaining materials like proteins, lipids, vitamins and minerals increases [15]. The shelf-life of fish is mainly related to microbial activity and nutritive value where the appearance, texture, color and flavor are also [10, 16]. Flavor which is originated from lipid and peptide components in the muscle is the most 
difficult to measure [15]. Two main parameters are pointed in conventional thawing processes which are the surface heat transfer coefficient and the surrounding medium temperature $[17,18]$. Rapid thawing at low temperatures may prolong the shelf life of fish by preventing the soluent losses and microbial and chemical changes [19]. This is a certain challenge for traditional thawing processes, where the lower temperature used remains between the frozen sample and the ambient, which is the principal driving power for the thawing process [17].

In this research, effect of different thawing techniques on the meat color of Black Sea trout was evaluated. For this reason, commonly used thawing methods by the consumers were applied on frozen fish fillets and color losses were determined.

\section{MATERIALS AND METHODS}

\section{Fish Material}

In this study, 70 individuals of cultured Black Sea trout approximately $2 \mathrm{~kg}$ each of them were used. First of all, cultured Black Sea trouts were obtained from marine cages unit in Central Fisheries Research Institute and bring to the laboratory with cold storage. In the latter, trouts were washed, cleaned their internal organs, removed their fins and filleted with a sharp fillet knife for the main study. Black sea trout individuals and fillets were shown in Figure 1.

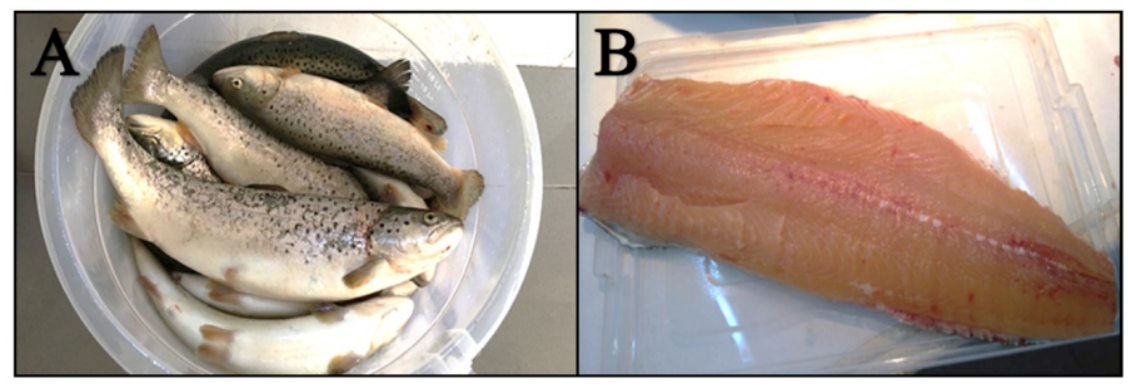

Figure 1. Black Sea trout individuals which are $2 \mathrm{~kg}$ each approximately (A), fillet of Black Sea trouts were used in main study (B).

\section{Freezing Procedure}

The fillets were divided into five different groups according to the thawing techniques to be applied in further. First group was not frozen with the aim of determination to color properties of fresh Black Sea trout meat and color measurements were carried out immediately. Rest of all were stored in zipper-bags which they placed in foam plates and frozen in $-20^{\circ} \mathrm{C}$ via deepfreezer for 7 days.

\section{Implementation of Thawing Techniques}

After the storage period, different thawing techniques were used. All techniques were carried

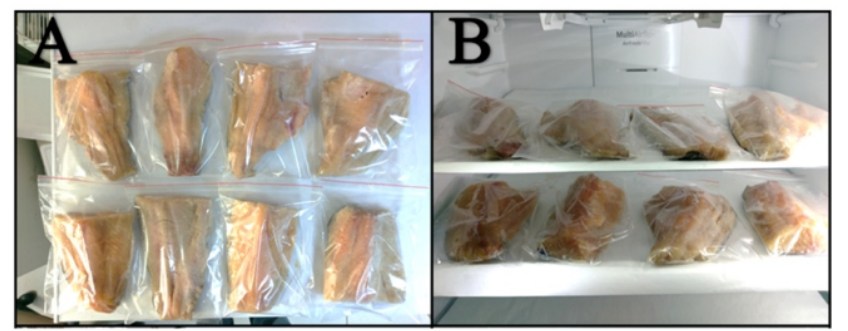

out till the all groups completely thawed. During thawing process, fillets were kept in zipper-bags except microwaved ones in order that minimizing external factors. In the first technique, frozen fillets were kept at room temperature $\left(+25^{\circ} \mathrm{C}\right)$ for 2 hours. In the second, frozen fillets were kept in refrigerator at $+4{ }^{\circ} \mathrm{C}$ for 12 hours. In the third one, frozen fillets were immersed in water-bath stabilized at $+15^{\circ} \mathrm{C}$ for 4 hours. Finally, last group of frozen fillets was thawed in Kenwood digital microwave oven (model: MV577, 900 watts) at defrost option (30\% power) for 6 minutes. All thawing techniques and conditions of techniques were shown in Figure 2 and Table 1.

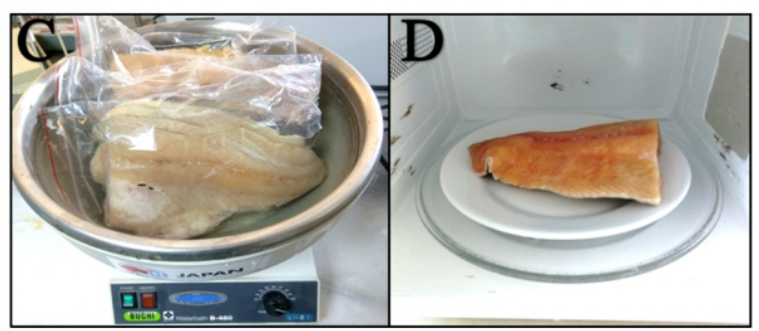

Figure 2. Thawing techniques applied to frozen trout fillets: thawing in room temperature at $+25^{\circ} \mathrm{C}(\mathrm{A})$, thawing in refrigerator at $+4{ }^{\circ} \mathrm{C}(\mathrm{B})$, thawing with immersion in water at $+15^{\circ} \mathrm{C}(\mathrm{C})$, thawing in microwave with defrost 
Table 1. Thawing conditions.

\begin{tabular}{lcccr}
\hline Thawing & $\begin{array}{c}\text { Freezing } \\
\text { Temp. }\end{array}$ & $\begin{array}{c}\text { Storage } \\
\text { Period }\end{array}$ & $\begin{array}{c}\text { Thawing } \\
\text { Temp. }\end{array}$ & $\begin{array}{r}\text { Thawing } \\
\text { Duration }\end{array}$ \\
\hline In room temp. & -20 & 7 days & $+25^{\circ} \mathrm{C}$ & $2 \mathrm{~h}$ \\
In refrigerator & -20 & 7 days & $+4^{\circ} \mathrm{C}$ & $12 \mathrm{~h}$ \\
In water (immersion) & -20 & 7 days & $+15^{\circ} \mathrm{C}$ & $4 \mathrm{~h}$ \\
In microwave (defrost)* & -20 & 7 days & $+25^{\circ} \mathrm{C}$ & $6 \mathrm{~min}$ \\
\hline
\end{tabular}

*Defrost option (30\% power) was set as automatically in microwave.

\section{Determination of Color Characteristics}

Color characteristics of thawed fillets and fresh meat were specified according to Minolta (1994) [20] by Konica Minolta CR-410 colorimeter with silicone photo cell detector and pulsed xenon lamb light source (Figure 3). In analysis, values of luminance (L), a and b (color-opponent dimensions) were specified. According to $\mathrm{L}^{*} \mathrm{a} * \mathrm{~b} *$ color chart; while the L value show lightness, a value indicates axis from green to red and $b$ value ranges from blue to yellow in a similar vein. Color differences $(\Delta E)$ were calculated with an equation mentioned by Zhu et al. (2004) [21]. This equation was given below:

$$
\Delta E=\sqrt{(\Delta L)^{2}+(\Delta a)^{2}+(\Delta b)^{2}}
$$

$\left(\Delta \mathrm{L}, \Delta \mathrm{a}\right.$ and $\Delta \mathrm{b}$ were differences on $\mathrm{L}^{*}, \mathrm{a}^{*}$ and $\mathrm{b}^{*}$ values between fresh meat and thawing technique).

Finally, obtained data were calculated by Color Data Software CM-S100w Spectra Magic ${ }^{\text {tm }}$ NX Lite and SPSS 21 statistic program. Differences between groups were determined by one-way analysis of variance ANOVA using Tukey's multiple comparison tests [22].

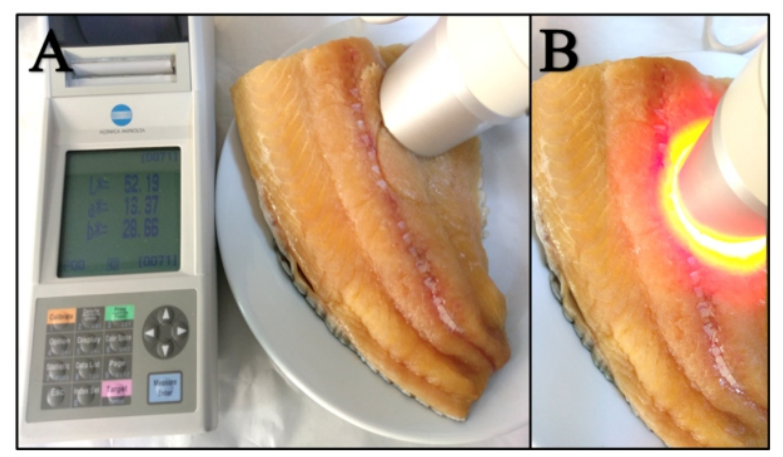

Figure 3. Determination of color characteristics: Conica Minolta CR-410 colorimeter (A) and using in measurements of color with with silicone photo cell detector and pulsed xenon lamb light source (B).

\section{RESULTS AND DISCUSSION}

The meat color is one of the most important quality parameters in Salmonid species [23]. According to Steine et al. (2004) consumers want pink-red salmon meat [24]. In salmonids, carotenoids are responsible for the characteristic pink color of meat $[25,26]$. Wild salmons contained approximately 10 times higher carotenoids than cultured ones [27]. Thus, with low carotenoid contents, color losses in cultured salmon become important. The color loss of trout meat mostly associated with oxidation of carotenoids, enzyme activity and temperature especially in frozen fish [28]. Freezing procedure is not responsible one of the significant factors which cause color changes in thawed fillets [21]. However, several thawing methods effects color of fish meat [11, 29, 30]. According to our results; color profile of fresh meat was found as $57.35 \pm 0.49\left(\mathrm{~L}^{*}\right), 8.83 \pm 0.26\left(\mathrm{a}^{*}\right)$ and $9.25 \pm 0.52$ $\left(b^{*}\right)$. These results show that meat of Black Sea trout is light colored than the Atlantic Salmon $[23,31]$. The highest $L$ value was specified in room temperature at $+25^{\circ} \mathrm{C}$, a value was specified in microwave and $b$ value was specified in microwave and room temperature at $+25^{\circ} \mathrm{C}$. The lowest $\mathrm{L}$ value was observed in microwaved ones, whereas $a$ and $b$ values were specified in refrigerator thawing. The color profiles of thawed fillets were shown in Table 2.

According to calculations of color differences; the most similar color profile to fresh trout meat was detected thawed in $+4^{\circ} \mathrm{C}$ ones. It can be related to low enzyme activity and slightly water loss in the surface area of fillets caused low temperature of refrigerator conditions than the other techniques. Second most similar color profile was observed in immersing thawing in similar vein. However, thawing in room temperature and thawing in microwave caused more color loss than the other two techniques. 
Table 2. Color profile of Black Sea trout' fillets

\begin{tabular}{lcccc}
\hline Thawing Techniques & $\mathrm{L}^{*}$ & $\mathrm{a}^{*}$ & $\mathrm{~b}^{*}$ & $\begin{array}{c}\text { Color } \\
\text { Differences }(\Delta \mathrm{E})\end{array}$ \\
\hline Fresh meat & $57.35 \pm 0.49^{\mathrm{b}}$ & $8.83 \pm 0.26^{\mathrm{c}}$ & $9.25 \pm 0.52^{\mathrm{c}}$ & - \\
In room temp. & $59.99 \pm 1.67^{\mathrm{a}}$ & $9.80 \pm 0.69^{\mathrm{c}}$ & $22.71 \pm 1.48^{\mathrm{a}}$ & $13.74 \pm 0.47^{\mathrm{b}}$ \\
In refrigerator & $56.08 \pm 1.02^{\mathrm{b}}$ & $7.63 \pm 0.55^{\mathrm{d}}$ & $10.58 \pm 0.92^{\mathrm{c}}$ & $2.20 \pm 0.15^{\mathrm{d}}$ \\
In water (immersion) & $57.42 \pm 0.92^{\mathrm{b}}$ & $12.30 \pm 0.85^{\mathrm{b}}$ & $18.66 \pm 1.10^{\mathrm{b}}$ & $10.03 \pm 0.22^{\mathrm{c}}$ \\
In microwave & $49.19 \pm 0.82^{\mathrm{c}}$ & $14.02 \pm 0.69^{\mathrm{a}}$ & $21.09 \pm 0.60^{\mathrm{a}}$ & $15.29 \pm 0.51^{\mathrm{a}}$ \\
(defrost) & & & & \\
\hline
\end{tabular}

Values are expressed as mean $\pm \mathrm{SD}(\mathrm{n}=3)$, mean values in column with different superscripts were significantly different $(\mathrm{P}<0.05)$.

Especially, analyze results show that microwaved fillets have extreme $\mathrm{L}$, $\mathrm{a}$ and $\mathrm{b}$ values among groups along with the most total color changes $(\Delta \mathrm{E})$. Fish fillets were exposed to different thawing temperatures due to the using technique in this study. Also, except the samples thawed in microwave, the others were all packed in same conditions to avoid surrounding environments' effects. The samples thawed at lower temperatures in refrigerator conditions unsurprisingly defrosted latter. In contrast to higher defrost period and exposing to the surrounding oxygen, discoloration is the lowest in samples thawed in refrigerator comparing the other samples. That's why loss of carotenoids which are responsible for pink color in trout fillets is more effective in discoloration than increasing enzyme activity by increasing the temperature and autoxidation because of surrounding oxygen. Thus, thawing at lower temperatures with lower oxygen levels contribute a better color profile in fish fillets. The total color changes of thawed fillets were shown in Table 2.

\section{CONCLUSION}

In view of the results, thawing of frozen fish fillets in refrigerator $\left(+4^{\circ} \mathrm{C}\right)$ is more preferable by the reason of their minimum color loss. Also, thawing in refrigerator is more reliable than other techniques considering food safety as well as more practical. Our findings will be contributed to the future work and these results attract all researchers.

\section{ACKNOWLEDGEMENTS}

This study was presented as a poster presentation in FABA 2016 International
Symposium on Fisheries and Aquatic Sciences at Antalya-Turkey.

\section{REFERENCES}

[1] Elliot, J.M. (1994) Quantitative ecology and the brown trout, Oxford Univ. Press, Oxford, UK.

[2] Sahlmann, C., Gu, J., Kortner, T.M., Lein, L., Krogdahl, A., and Bakke, A.M. (2015) Ontogeny of the digestive system of atlantic salmon (Salmo salar L.) and effects of soybean meal from start-feeding, J. Plosone. $10,1-23$.

[3] Froese, R., and Pauly, D. (2017) FishBase. Retrieved from www.fishbase.org.

[4] Aydin, H., and Yand1, I. (2002) The general status of spawning areas of blacksea trout in the east Blacksea regions (Salmo trutta labrax Pallas, 1811), E.U. J. Fish. Aquat. Sci. 19, 501-506.

[5] Çankırılıgil, E.C., Çakmak, E., Özel, O.T., and Kasapoglu, N. (2017) Black Sea trout (Salmo trutta labrax PALLAS, 1811) culture in Turkey and morphometric characteristics of fifth culture generation, in: Abstr. B. SEAB 2017, Int. Symp. EuroAsian Biodivers., Minsk, Belarus, p. 87.

[6] Azam, K., and Mackie, I.M. (1989) The effect of slaughter method on the quality of rainbow trout (Salmo gairdneri) during storage on ice, Int. J. Food Sci. Technol., 24, 69-79.

[7] Magnusson, O.M., and Johansen, S. (1990) Influence of handling and slaughtering on quality of farmed fish, in: Chill. Freez. New Fish Prod., pp. 317-222. 
[8] Nilsson, K., and Ekstrand, B.O. (1995) Sensory and chemically measured effects of different freeze treatments on the quality of farmed rainbow trout, J. Food Qual., 18, 177-191.

[9] Sigurgisladottir, S., Ingvarsdottir, H., Torrissen, O.J., Cardinal, M., and Hafsteinsson, H. (2000) Effects of freezing/thawing on the microstructure and the texture of smoked atlantic salmon (Salmo salar), Food Res. Int., 33, 857-865. doi:10.1016/S0963-9969(00)00105-8.

[10] García-Arias, M.T., Alvarez-Pontes, E., García-Fernández, M.C., and SánchezM un i z, F. J. $\quad\left(\begin{array}{llll}2 & 0 & 0 & 3\end{array}\right)$ Freezing/defrosting/frying of sardine fillets. Influence of slow and quick defrosting on protein quality, J. Sci. Food Agric., 83, 602-608. doi:10.1002/jsfa.1366.

[11] Ersoy, B., Aksan, E., and Özeren, A. (2008) The effect of thawing methods on the quality of eels (Anguilla anguilla), Food Chem., 111, $\begin{array}{lllllll}3 & 7 & 7 & - & 3 & 8 & 0\end{array}$. doi:10.1016/j.foodchem.2008.03.081.

[12] Nemethy, G. (1966) Structure of water and of aqueous solutions, Cryobiology. 3, 19-26.

[13] Benjakul, S., and Bauer, F. (2001) Biochemical and physicochemical changes in catfish (Silurus glanis Linne) muscle as influenced by different freeze-thaw cycles, F o o d C h e m., $72,207-217$. doi:10.1016/S0308-8146(00)00222-3.

[14] Benjakul, S., and Bauer, F. (2000) Physicochemical and enzymatic changes of cod muscle proteins subjected to different freeze-thaw cycles, J. Sci. Food Agric., 80, $1143-1150$. doi:10.1002/1097$0010(200006) 80: 8<1143:$ : A ID JSFA610>3.0.CO;2-C.

[15] Leygonie, C., Britz, T.J., and Hoffman, L.C. (2012) Impact of freezing and thawing on the quality of meat: Review, Meat Sci., 91, 93-98. doi:10.1016/j.meatsci.2012.01.013.

[16] McMillin, K.W. (2008) Where is MAP Going? A review and future potential of modified atmosphere packaging for meat, $\mathrm{M}$ e a t $\mathrm{S}$ c i . , $80,43-65$. doi:10.1016/j.meatsci.2008.05.028.

[17] Alizadeh, E., Chapleau, N., De Lamballerie, M., and LeBail, A. (2007) Effects of freezing and thawing processes on the quality of Atlantic salmon (Salmo salar) fillets, J. Food Sci., 72, 279-284. doi:10.1111/j.1750- 3841.2007.00355.x.

[18] Schubring, R., Meyer, C., Schlüter, O., Boguslawski, S., and Knorr, D. (2003) Impact of high pressure assisted thawing on the quality of fillets from various fish species, Innov. Food Sci. Emerg. Technol., 4, 257-267. doi:10.1016/S14668564(03)00036-5.

[19] Okamoto, A., and Suzuki, A. (2002) Effects of high hydrostatic pressure-thawing on pork meat, Trends High Press. Biosci. Biotechnol., 571-576.

[20] Minolta (1994) Color control from feeling to instrumentation, Precise Color Communication.

[21] Zhu, S., Ramaswamy, H.S., and Simpson, B.K. (2004) Effect of high-pressure versus conventional thawing on color, drip loss and texture of Atlantic salmon frozen by different methods, LWT - Food Sci. Technol., 37, 291-299. doi:10.1016/j.lwt.2003.09.004.

[22] Zar, J. (1999). Biostatistical analysis. India: Pearson Education.

[23] Erikson, U., and Misimi, E. (2008) Atlantic salmon skin and fillet color changes effected by perimortem handling stress, rigor mortis, and 1ce storage, J. Food Sci. 73, 50-59. doi:10.1111/j.1750-3841.2007.00617.x.

[24] Steine, G., Alfnes, F., and Rora, M.B. (2004) Consumer attitudes towards salmon color : a stated choice experiment with pictures, Mar. Resour. Econ., 1-20.

[25] Anderson, S. (2000) Salmon color and the consumer, in: IIFET 2000 Proc. B., pp. 1-3.

[26] Buttle, L.G., Crampton, V.O., and Williams, P.D. (2001) The effect of feed pigment deposition and colour in farmed Atlantic salmon , Salmo salar L ., Aquac. Res., 32, 103-111.

[27] Chitchumroonchokchai, C., and Failla, M.L. (2017) Bioaccessibility and intestinal cell uptake of astaxanthin from salmon and commercial supplements, Food Res. Int., 99, $\begin{array}{lllllll}9 & 3 & 6 & - & 9 & 4 & 3\end{array}$. doi:10.1016/j.foodres.2016.10.010.

[28] Venugopal, V. (2006) Postharvest quality changes and safety hazards, in: Seaf. Process., Taylor \& Francis, Boca Raton,: p. 32.

[29] Dinçer, T., Cadun, A., Çaklı, Ş., and Tolasa, Ş. (2009) Effects of different thawing methods on the freshness quality of fish, Aquat. Sci., 26, 253-256. 
[30] Alberio, G.R.A., Barbagallo, R.N., Todaro, A., Bono, G., and Spagna, G. (2014) Effect of freezing/thawing process in different sizes of blue fish in the Mediterranean through lysosomal enzymatic tests, Food Chem., 148, 47-5. doi:10.1016/j.foodchem.2013.10.013.

[31] Misimi, E., Mathiassen, J.R., and Erikson, U. (2007) Computer vision-based sorting of Atlantic salmon (Salmo salar) fillets according to their color level., J. Food Sci., $72,1-6$. doi: $10.1111 / \mathrm{j} .1750$ 3841.2006.00241.x. 